\title{
PENGARUH SUPLEMENTASI TEPUNG KULIT MANGGIS DAN VITAMIN E DI DALAM RANSUM AYAM RAS PETELUR STRAIN LOHMANN TERHADAP KUALITAS FISIK TELUR YANG DISIMPAN PADA WAKTU DAN SUHU YANG BERBEDA
}

\section{EFFECT OF MANGOSTEEN PERICARP MEAL AND VITAMIN E SUPPLEMENTED IN THE DIET OF LAYING HENS LOHMANN STRAIN ON PHYSICAL QUALITY OF EGG AFTER STORAGE IN DIFFERENT TIME AND TEMPERATURE}

\author{
Rita Mutia $^{{ }^{*}}$, Ridho Kurniawan Rusli ${ }^{1}$, Komang Gede Wiryawan ${ }^{1}$, Toto Toharmat ${ }^{1}$, dan \\ Jakaria $^{2}$ \\ ${ }^{1}$ Departemen IImu Nutrisi dan Teknologi Pakan, Fakultas Peternakan, Institut Pertanian Bogor, Bogor, \\ 16680 \\ ${ }^{2}$ Departemen IImu Produksi dan Teknologi Peternakan, Fakultas Peternakan, Institut Pertanian Bogor, \\ Bogor, 16680
}

Submitted: 18 November 2016, Accepted: 13 January 2017

\section{INTISARI}

Penelitian ini bertujuan untuk mengkaji pengaruh suplementasi tepung kulit manggis (TKM) dan Vitamin $E(V E)$ di dalam ransum ayam ras petelur terhadap kualitas fisik telur selama penyimpanan pada waktu dan suhu yang berbeda. Ayam petelur diberi perlakuan pakan yaitu : R0 (ransum kontrol), R1 (R0 + $1 \mathrm{~g} \mathrm{TKM} / \mathrm{Kg}$ ransum), R2 (R0 + $2 \mathrm{~g}$ TKM/Kg ransum) dan $\mathrm{R} 3(\mathrm{R} 0+200 \mathrm{mg}$ VE/Kg ransum). Rancangan yang digunakan adalah rancangan acak lengkap pola faktorial $4 \times 3 \times 2$ dengan 4 ulangan. Faktor pertama yaitu ransum, faktor kedua yaitu: waktu penyimpanan (1,2 dan 3 minggu) dan faktor ketiga yaitu suhu penyimpanan pada refrigerator $\left(4,13^{\circ} \mathrm{C}\right.$ dan $\left.22,50 \%\right)$ dan suhu ruang $\left(27,47^{\circ} \mathrm{C}\right.$ dan $\left.76,17 \%\right)$. Variabel yang diamati adalah: berat telur, persentase kerabang telur, persentase kuning telur, persentase putih telur, tebal kerabang, warna kuning telur dan Haught unit (HU). Hasil penelitian menunjukkan bahwa interaksi antara ransum, waktu dan suhu selama penyimpanan sangat nyata $(P<0,01)$ menurunkan warna kuning telur Waktu dan suhu penyimpanan sangat nyata $(P<0,01)$ menurunkan $\mathrm{HU}$ dan meningkatkan persentase kuning telur. Interaksi waktu dan suhu penyimpanan nyata $(P<0,05)$ menurunkan persentase putih telur. Tebal kerabang nyata $(P<0,05)$ meningkat dipengaruhi oleh ransum dan sangat nyata $(P<0,01)$ meningkat dipengaruhi oleh waktu penyimpanan. Berat telur dan persentase kerabang telur tidak dipengaruhi oleh ransum, waktu dan suhu penyimpanan. Kesimpulan penelitian adalah suplementasi tepung kulit manggis dan Vitamin E di dalam ransum ayam ras petelur strain Lohmann secara umum tidak mempengaruhi kualitas fisik telur (kecuali warna kuning telur dan tebal kerabang) yang disimpan pada waktu dan suhu yang berbeda. Kualitas fisik telur lebih utama dipengaruhi oleh waktu dan suhu penyimpanan yang berbeda. Suhu dan kelembaban terbaik untuk penyimpanan telur adalah $4,13^{\circ} \mathrm{C}$ dan $22,50 \%$ pada refrigerator, pada kondisi ini telur dapat disimpan selama 21 hari.

(Kata kunci: Kualitas fisik telur, Suhu penyimpanan, Tepung kulit manggis, Vitamin E, Waktu penyimpanan)

\section{ABSTRACT}

This research aimed to study the effect of mangosteen pericarp meal (MPM) and vitamin E (VE) supplemented in the diet of laying hens lohmann strain on physical quality of egg during storage at different time and temperature. The laying hens were given the treatments i.e. R0 (control feed), $R 1$ (R0 + $1 \mathrm{~g}$ $M P M / K g$ ration), $R 2$ ( $R 0+2 \mathrm{~g} M P M / K g$ ration) and $R 3(R 0+200 \mathrm{mg}$ VE/Kg ration). Statistical designs were completely randomized design $4 \times 3 \times 2$ with four replications. The factor were rations, storage time $\left(1^{\text {st }}, 2^{\text {nd }}\right.$ and $3^{\text {rd }}$ week), and storage temperature (refrigerator: $4.13^{\circ} \mathrm{C}$ and $22.50 \%$ and room temperature: $27.47^{\circ} \mathrm{C}$ and $76.17 \%$ ) respectively. The experimental variable were egg weight, percentage of egg shell, percentage of yolk, percentage of albumen, egg shell thickness, yolk color, and Haugh unit (HU). The results showed that interactions between rations, storage time and temperature significantly $(P<0.01)$ decreased yolk color. The storage time and temperature significantly $(P<0.01)$ decreased $\mathrm{HU}$ and increased percentage of yolk. The interactions between storage time and temperature significantly $(P<0.05)$ decreased percentage of albumen. Egg shell significantly $(P<0.05)$ increased affected by rations and significantly $(P<0.01)$ increased affected by storage time. Egg weight and percentage of egg shell was not affected by rations, storage time and temperature. It was concluded that supplementation of mangosteen pericarp meal and

\footnotetext{
${ }^{*}$ Korespondensi (corresponding author):

Telp. +62 8521792 3399, E-mail: rmutia.1@gmail.com
} 
vitamin $E$ in the diet of laying hens lohmann strain generally did not affect physical quality of egg (except yolk color and egg shell) stored at the different time and temperature. The main physical quality of egg is affected by different time and storage temperatures. The suggested temperature and humidity for egg storage is $4.13^{\circ} \mathrm{C}$ and $22.50 \%$ at referigerator, in these conditions the eggs can be stored for 21 days.

(Key words: Mangosteen pericarp meal, Physical quality, Storage temperature, Storage time, Vitamin E)

\section{Pendahuluan}

Telur merupakan salah satu produk peternakan yang dapat diandalkan sebagai sumber protein hewani. Selain kaya nutrisi, harganya relatif terjangkau dan mudah didapatkan oleh konsumen. Namun demikian, telur juga mudah mengalami penurunan kualitas (eksternal dan internal) yang disebabkan oleh bakteri, penyimpanan, benturan dan bahan kimia. Faktor penyimpanan telur menjadi fokus perhatian, karena daya simpan telur relatif singkat. Badan Standarisasi Nasional (2008) menyatakan bahwa pada suhu ruang telur hanya bertahan 14 hari, setelah itu telur mengalami kerusakan.

Upaya yang dilakukan agar telur dapat disimpan lebih lama dan kualitas dapat dipertahankan salah satunya dengan teknologi pengawetan. Pengawetan telur dapat dilakukan dengan proses pengasinan dan perendaman. Beberapa hasil penelitian tentang pengawetan menggunakan bahan alami seperti: garam (Wulandari, 2004), minyak kelapa, kapur sirih, ekstrak bunga rosela (Rahmawati et al., 2014), larutan kulit manggis (Cornelia et al., 2014) dan abu pelepah kelapa sawit (Yosi et al., 2016) terbukti dapat mempertahankan daya simpan telur.

Salah satu cara untuk mempertahankan kualitas telur selama disimpan adalah dengan strategi nutrisi melalui suplementasi nutrien spesifik ke dalam ransum. Kandidat nutrien yang akan digunakan adalah kulit manggis dan vitamin E. Kulit manggis mengandung xanthone dan turunannya (Jung et al., 2006), anthocyanins (Palapol et al., 2009), saponin dan tanin (Rusli et al., 20015a). Hasil-hasil penelitian menunjukkan bahwa senyawa yang terdapat di dalam kulit manggis memiliki khasiat seperti: antioksidan (Suvarnakuta et al., 2011) dan anti bakteri (Gutierrez-Orozco dan Failla, 2013). Istiqomah et al. (2013) menyatakan bahwa penambahan $1 \%$ tepung kulit manggis di dalam pakan dapat meningkatkan berat telur dan indeks warna kuning telur itik Mojosari. Rusli et al. (2015a) menyatakan bahwa suplementasi tepung kulit manggis 1-2 $\mathrm{g} / \mathrm{Kg}$ di dalam ransum ayam petelur terbukti dapat meningkatkan aktivitas enzim superoxide dismutase (SOD) dan menurunkan kandungan thiobarbituric acid reactive substances (TBARS) pada kuning telur ayam, akan tetapi menurut Rusli et al. (2015b) bahwa suplementasi tepung kulit manggis tidak mempengaruhi kualitas fisik telur seperti: berat telur, persentase kerabang telur, persentase kuning telur, persentase albumen, warna kuning telur, warna kerabang telur dan Haugh unit.

Vitamin $E(V E)$ merupakan salah satu vitamin yang berfungsi sebagai antioksidan, melindungi struktur seluler dan menjaga stabilitas membran dari kerusakan oleh radikal bebas (Putphpongsiriporn et al., 2001; Jiang et al., 2013). Beberapa hasil penelitian menunjukkan bahwa pemberian $200 \mathrm{mg}$ VE di dalam ransum ayam petelur tidak mempengaruhi warna kuning telur, kekuatan kerabang, tebal kerabang dan Haugh unit (Jiang et al., 2013). Hasil yang sama juga diperoleh Irandoust et al. (2012) yang menyatakan bahwa suplementasi $250 \mathrm{mg}$ $\mathrm{VE} / \mathrm{kg}$ ransum tidak mempengaruhi kualitas telur. Pemberian $200 \mathrm{mg}$ VE dapat meningkatkan persentase kuning telur dan menurunkan persentase albumen telur ayam dibandingkan perlakuan tanpa vitamin E (Jiang et al., 2013). Ciftci et al. (2005) menyatakan bahwa pakan dengan kandungan vitamin $E$ yang tinggi dapat meningkatkan kandungan $\alpha$-tocopherol pada kuning telur, hal ini disebabkan oleh vitamin $\mathrm{E}$ disimpan dalam jaringan sebagai vitamin yang larut dalam lemak, sehingga konsentrasi a-tocopherol di dalam plasma dan jaringan juga meningkat. Scheideler et al. (2010) menyatakan bahwa terjadi kompetisi metabolisme dan pengangkutan mineral Se dengan vitamin $\mathrm{E}$ pada kuning telur, apabila konsentrasi vitamin $\mathrm{E}$ meningkat maka secara linear konsentrasi vitamin $\mathrm{E}$ pada kuning telur juga meningkat, namun apabila konsentrasi Se meningkat maka konsentrasi vitamin $\mathrm{E}$ menurun pada kuning telur.

Penelitian tentang penggunaan tepung kulit manggis dan vitamin $\mathrm{E}$ di dalam ransum 
terhadap kualitas fisik telur ayam yang disimpan pada waktu dan suhu penyimpanan yang berbeda masih terbatas, oleh karena itu dilakukan penelitian untuk mengkaji pengaruh suplementasi tepung kulit manggis (TKM) dan Vitamin $E$ (VE) di dalam ransum ayam ras petelur strain Lohmann terhadap kualitas fisik telur selama penyimpanan pada waktu dan suhu yang berbeda.

\section{Materi dan Metode}

\section{Materi}

Penelitian ini menggunakan sampel telur ayam ras petelur strain Lohmann (Japfa Comfeed, Indonesia). Ayam ras petelur dipelihara sebanyak 160 ekor selama 11 minggu, terdiri atas 4 perlakuan ransum $(\mathrm{R} 0=$ ransum kontrol, $\mathrm{R} 1=\mathrm{R} 0+1 \mathrm{~g} \mathrm{TKM} / \mathrm{Kg}$ ransum, $\mathrm{R} 2=\mathrm{R} 0+2 \mathrm{~g} T \mathrm{TKM} / \mathrm{Kg}$ ransum, dan $\mathrm{R} 3=\mathrm{R} 0+200 \mathrm{mg} \mathrm{VE} / \mathrm{Kg}$ ransum) dengan 4 ulangan (10 ekor ayam petelur setiap ulangan). Ransum disusun berdasarkan Leeson dan Summers (2005) dengan kandungan energi metabolis: $2900 \mathrm{Kkal} / \mathrm{Kg}$, protein kasar: $17 \%$, Ca: $3,83 \%$ dan $\mathrm{P}$ tersedia: $0,49 \%$.

Pengambilan sampel untuk uji kualitas telur dilakukan pada akhir penelitian. Telur diambil sebanyak 3 butir untuk setiap ulangan pada masing-masing perlakuan, kemudian telur diletakkan pada egg tray dengan posisi telur bagian ujung yang tumpul sebelah atas dan bagian yang lancip di bagian bawah untuk disimpan selama satu minggu pada refrigerator dan suhu ruang. Pengambilan sampel telur untuk penyimpanan selama dua minggu dan tiga minggu pada refrigerator dan suhu ruang memiliki prosedur yang sama dengan pengambilan telur untuk penyimpanan satu minggu.

\section{Metode}

Rancangan percobaan yang digunakan dalam penelitian ini adalah rancangan acak lengkap pola faktorial $4 \times 3 \times$ 2 dengan 4 ulangan. Faktor pertama yaitu ransum (ransum kontrol, suplementasi $1 \mathrm{~g}$ $\mathrm{TKM} / \mathrm{Kg}$ ransum, $2 \mathrm{~g}$ TKM/Kg ransum dan 200 $\mathrm{mg} \mathrm{VE/kg} \mathrm{ransum),} \mathrm{faktor} \mathrm{kedua} \mathrm{yaitu} \mathrm{:} \mathrm{waktu}$ penyimpanan (1, 2 dan 3 minggu) dan faktor ketiga yaitu suhu penyimpanan pada refrigerator $\left(4,13^{\circ} \mathrm{C}\right.$ dan $\left.22,50 \%\right)$ dan suhu ruang $\left(27,47^{\circ} \mathrm{C}\right.$ dan $\left.76,17 \%\right)$.

Telur yang telah disimpan sesuai dengan perlakuan kemudian dianalisis berdasarkan parameter yang telah ditentukan dengan metode masing-masing. Parameter yang diamati terdiri dari: berat telur ( $\mathrm{g} / \mathrm{butir}$ ), diukur dengan cara menimbang telur dengan menggunakan timbangan digital (Osuka$\mathrm{HWH}^{\circledR}$, Japan). Persentase kuning telur (\%), dihitung dengan membagi berat kuning telur dengan berat telur kemudian dikali 100 . Persentase putih telur (\%), dihitung dengan membagi berat putih telur dengan berat telur kemudian dikali 100. Tebal kerabang $(\mathrm{mm})$, ditentukan dengan menggunakan jangka sorong digital (150 Digital Caliper, Nankai ${ }^{\circledR}$, Japan). Warna kuning telur, ditentukan dengan cara membandingkan dengan standar warna kuning telur pada Egg Roche Yolk Colour Fan (Ovo Color, BASF Aktiengesellscharft, Germany). Haught unit (HU), diperoleh dari perhitungan berdasarkan Buckle et al. (1987) yaitu: $\mathrm{HU}=100 \log [(\mathrm{H}+$ 7.57)-(1.7 $\left.\times \mathrm{W}^{0.37}\right)$ ], $\mathrm{H}$ adalah tinggi albumen $(\mathrm{mm})$ dan $\mathrm{W}$ adalah berat telur $(\mathrm{g})$.

\section{Analisis data}

Analisis statistik data menggunakan analisis of variance (ANOVA) dengan menggunakan Statistical Package for Social Sciences $\left(\right.$ IBM $^{\circledR}$ SPSS ${ }^{\circledR}$ versi 21.0), untuk melihat perbedaan antar perlakuan dilakukan uji duncan multiple range test (DMRT), jika terdapat interaksi maka dilakukan uji lanjut untuk memeriksa pengaruh sederhana dari taraf masing-masing faktor menggunakan rancangan acak lengkap (RAL) faktor tunggal.

\section{Hasil dan Pembahasan}

\section{Suhu dan kelembaban relatif pada ruang penyimpanan}

Rerata suhu dan kelembaban relatif selama penyimpanan telur disajikan pada Tabel 1. Hasil penelitian menunjukkan bahwa kisaran suhu dan kelembaban selama penelitian yaitu $26-28^{\circ} \mathrm{C}$ dan $69-86 \%$ pada suhu ruang, sedangkan pada refrigerator antara $3,55-4,45^{\circ} \mathrm{C}$ dan $18,50-25 \%$ Suhu dan kelembaban perlu untuk diketahui karena merupakan salah satu faktor yang mempengaruhi kualitas telur (USDA, 2000). Badan Standarisasi Nasional (2008) menyatakan bahwa pada suhu ruang dengan kelembaban antara $80-90 \%$ telur hanya mampu bertahan selama 14 hari setelah oviposition, atau pada temperatur antara 4$7^{\circ} \mathrm{C}$ dengan kelembaban antara $60-70 \%$ maksimum selama 30 hari setelah oviposition. 


\section{Kualitas fisik telur}

Hasil penelitian pengaruh ransum, waktu dan suhu penyimpanan terhadap berat telur (disajikan pada Tabel 2), warna kuning telur (disajikan pada Tabel 3), Haugh unit (disajikan pada Tabel 4), tebal kerabang (disajikan pada Tabel 5), persentase kuning telur (disajikan pada Tabel 6), persentase putih telur (disajikan pada Tabel 7).

Berdasarkan analisis ragam, diperoleh hasil bahwa interaksi antara ransum, waktu dan suhu selama penyimpanan sangat nyata $(P<0,01)$ menurunkan warna kuning telur. Waktu dan suhu penyimpanan sangat nyata $(P<0,01)$ menurunkan $\mathrm{HU}$ dan meningkatkan persentase kuning telur. Interaksi waktu dan suhu penyimpanan nyata $(P<0,05)$ menurunkan persentase putih telur. Tebal kerabang nyata $(P<0,05) \quad$ meningkat dipengaruhi oleh ransum dan sangat nyata $(P<0,01)$ meningkat dipengaruhi oleh waktu penyimpanan. Berat telur dan persentase kerabang telur tidak nyata $(P>0,05)$ dipengaruhi oleh ransum, waktu dan suhu penyimpanan.

Analisis lebih lanjut menunjukkan bahwa pengaruh ransum kontrol menghasilkan warna kuning telur yang sangat nyata $(P<0,01)$ lebih rendah selama penyimpanan tiga minggu jika dibandingkan dengan warna kuning telur yang disimpan selama satu dan dua minggu. Ransum

Tabel 1. Rerata suhu dan kelembaban relatif selama penyimpanan telur (the average of temperature and relative humidity during eggs storage)

\begin{tabular}{|c|c|c|c|c|c|c|}
\hline \multirow{2}{*}{$\begin{array}{l}\text { Waktu penyimpanan } \\
\text { (storage time) } \\
\text { (place) }\end{array}$} & \multicolumn{2}{|c|}{$\begin{array}{l}1 \text { minggu } \\
\left(1^{\text {st }} \text { week }\right)\end{array}$} & \multicolumn{2}{|c|}{$\begin{array}{l}2 \text { minggu } \\
\left(2^{\text {nd }} \text { week }\right)\end{array}$} & \multicolumn{2}{|c|}{$\begin{array}{l}3 \text { minggu } \\
\left(3^{r d} \text { week }\right)\end{array}$} \\
\hline & $\begin{array}{c}\text { Suhu }\left({ }^{0} \mathrm{C}\right) \\
\text { (temperature } \\
\left.\left({ }^{0} \mathrm{C}\right)\right)\end{array}$ & $\begin{array}{c}\text { Kelembaban (\%) } \\
\text { (humidity (\%)) }\end{array}$ & $\begin{array}{c}\text { Suhu }\left({ }^{\circ} \mathrm{C}\right) \\
\text { (temperature } \\
\left.\left({ }^{0} \mathrm{C}\right)\right)\end{array}$ & $\begin{array}{c}\text { Kelembaban } \\
(\%) \\
\text { (humidity (\%)) }\end{array}$ & $\begin{array}{c}\text { Suhu }\left({ }^{0} \mathrm{C}\right) \\
(\text { temperature } \\
\left.\left({ }^{0} \mathrm{C}\right)\right)\end{array}$ & $\begin{array}{c}\text { Kelembaban } \\
(\%) \\
\text { (humidity (\%)) }\end{array}$ \\
\hline $\begin{array}{l}\text { Referigerator } \\
\text { (refrigerator) }\end{array}$ & $3,55 \pm 0,64$ & $18,50 \pm 4,95$ & $4,40 \pm 0,57$ & $24,00 \pm 2,83$ & $4,45 \pm 0,49$ & $25,00 \pm 1,41$ \\
\hline $\begin{array}{l}\text { Suhu ruang (room } \\
\text { temperature) }\end{array}$ & $26,65 \pm 0,35$ & $86,00 \pm 9,90$ & $28,35 \pm 0,21$ & $69,50 \pm 4,95$ & $27,40 \pm 0,42$ & $73,00 \pm 5,66$ \\
\hline
\end{tabular}

Tabel 2. Pengaruh ransum, waktu dan suhu penyimpanan terhadap berat telur $(\mathrm{g})^{\mathrm{ns}}$ (effect of ration, storage time and temperature on egg weight $(g))^{\text {ns }}$

\begin{tabular}{|c|c|c|c|c|c|}
\hline \multirow{2}{*}{$\begin{array}{l}\text { Ransum } \\
\text { (rations) }\end{array}$} & \multirow{2}{*}{$\begin{array}{l}\text { Suhu penyimpanan } \\
\text { (temperature storage) }\end{array}$} & \multicolumn{3}{|c|}{$\begin{array}{c}\text { Waktu penyimpanan (minggu) } \\
\text { (Storage time (week)) }\end{array}$} & \multirow{2}{*}{$\begin{array}{c}\text { Rerata } \\
\text { ransum*suhu } \\
\text { (rations*tem- } \\
\text { perature } \\
\text { average) }\end{array}$} \\
\hline & & $\begin{array}{c}1 \\
\left(1^{s t}\right)\end{array}$ & $\begin{array}{c}2 \\
\left(2^{n d}\right)\end{array}$ & $\begin{array}{c}3 \\
\left(3^{r d}\right)\end{array}$ & \\
\hline \multirow{2}{*}{ Ro } & Referigerator (refrigerator) & $50,95 \pm 2,55$ & $58,65 \pm 3,39$ & $51,78 \pm 2,46$ & $53,79 \pm 4,42$ \\
\hline & Suhu ruang (room temperature) & $54,98 \pm 1,34$ & $53,35 \pm 4,26$ & $52,68 \pm 6,80$ & $53,67 \pm 4,37$ \\
\hline \multicolumn{2}{|c|}{$\begin{array}{l}\text { Rerata ransum* waktu (rations* storage time } \\
\text { average) }\end{array}$} & $52,96 \pm 2,86$ & $56,00 \pm 4,55$ & $52,23 \pm 4,76$ & $53,73 \pm 4,30$ \\
\hline \multirow{2}{*}{$\mathrm{R} 1$} & Referigerator (refrigerator) & $53,65 \pm 4,66$ & $52,95 \pm 2,68$ & $50,73 \pm 3,05$ & $52,44 \pm 3,48$ \\
\hline & Suhu ruang (room temperature) & $51,55 \pm 3,47$ & $53,73 \pm 4,94$ & $52,30 \pm 2,23$ & $52,53 \pm 3,48$ \\
\hline \multicolumn{2}{|c|}{$\begin{array}{l}\text { Rerata ransum* waktu (rations* storage time } \\
\text { average) }\end{array}$} & $52,60 \pm 3,97$ & $53,34 \pm 3,69$ & $51,51 \pm 2,69$ & $52,48 \pm 3,41$ \\
\hline \multirow{2}{*}{$\mathrm{R} 2$} & Referigerator (refrigerator) & $56,83 \pm 4,44$ & $52,63 \pm 4,66$ & $52,90 \pm 3,23$ & $54,12 \pm 4,26$ \\
\hline & Suhu ruang (room temperature) & $52,35 \pm 2,94$ & $48,88 \pm 2,56$ & $53,35 \pm 4,04$ & $51,53 \pm 3,55$ \\
\hline \multicolumn{2}{|c|}{$\begin{array}{l}\text { Rerata ransum* waktu (rations* storage time } \\
\text { average) }\end{array}$} & $54,59 \pm 4,23$ & $50,75 \pm 4,02$ & $53,13 \pm 3,39$ & $52,82 \pm 4,06$ \\
\hline \multirow{2}{*}{ R3 } & Referigerator (refrigerator) & $55,60 \pm 1,12$ & $53,40 \pm 4,88$ & $50,13 \pm 7,47$ & $53,04 \pm 5,25$ \\
\hline & Suhu ruang (room temperature) & $57,20 \pm 2,56$ & $52,70 \pm 1,58$ & $53,00 \pm 7,15$ & $54,30 \pm 4,58$ \\
\hline \multicolumn{2}{|c|}{$\begin{array}{l}\text { Rerata ransum* waktu (rations* storage time } \\
\text { average) }\end{array}$} & $56,40 \pm 2,02$ & $53,05 \pm 3,38$ & $51,56 \pm 6,94$ & $53,67 \pm 4,86$ \\
\hline \multicolumn{2}{|c|}{ Rerata waktu penyimpanan (storage time average) } & $54,14 \pm 3,56$ & $53,28 \pm 4,19$ & $52,11 \pm 4,54$ & \\
\hline \multirow{2}{*}{$\begin{array}{l}\text { Rerata suhu } \\
\text { (tempera-ture } \\
\text { average) }\end{array}$} & Referigerator (refrigerator) & $54,26 \pm 3,88$ & $54,41 \pm 4,40$ & $51,38 \pm 3,55$ & $53,35 \pm 4,31$ \\
\hline & Suhu ruang (room temperature) & $54,02 \pm 3,33$ & $52,16 \pm 3,78$ & $52,83 \pm 4,89$ & $53,00 \pm 4,04$ \\
\hline
\end{tabular}


dengan suplementasi $1 \mathrm{~g}$ TKM/kg ransum menghasilkan warna kuning telur sangat nyata $(P<0,01)$ lebih rendah selama penyimpanan tiga minggu jika dibandingkan dengan warna kuning telur yang disimpan selama satu dan dua minggu. Ransum dengan suplementasi $2 \mathrm{~g}$ TKM/kg ransum menghasilkan warna kuning telur sangat nyata $(P<0,01)$ lebih rendah selama penyimpanan tiga minggu jika dibandingkan dengan warna kuning telur yang disimpan selama satu dan dua minggu.

Hasil analisis menunjukkan bahwa pengaruh sederhana ransum dengan suplementasi $1 \mathrm{~g} \quad \mathrm{TKM} / \mathrm{kg}$ ransum menghasilkan warna kuning telur nyata $(P<0,05)$ lebih tinggi selama penyimpanan pada suhu refrigerator dibandingkan warna kuning telur yang disimpan pada suhu ruang. Ransum dengan suplementasi $2 \mathrm{~g}$ TKM/kg ransum menghasilkan warna kuning telur nyata $(P<0,05)$ lebih tinggi selama penyimpanan pada suhu referigerator dibandingkan warna kuning telur yang disimpan pada suhu ruang. Pengaruh sederhana penyimpanan pada suhu ruang menghasilkan warna kuning telur nyata $(P<0,05)$ lebih tinggi pada ransum kontrol dan ransum suplementasi $200 \mathrm{mg} \mathrm{VE/kg} \mathrm{ransum}$ dibandingkan warna kuning telur dengan suplementasi 1 dan $2 \mathrm{~g} \mathrm{TKM} / \mathrm{kg}$ ransum.

Analisis lebih lanjut menunjukkan bahwa pengaruh sederhana waktu penyimpanan selama dua minggu menghasilkan warna kuning telur yang nyata $(P<0,05)$ lebih tinggi pada suhu referigerator jika dibandingkan dengan warna kuning telur pada suhu ruang. Pengaruh sederhana penyimpanan pada suhu referigerator menghasilkan warna kuning telur sangat nyata $(P<0,01)$ lebih tinggi pada penyimpanan selama satu dan dua minggu jika dibandingkan dengan warna kuning telur pada penyimpanan selama tiga minggu.

Hasil analisis persentase putih telur menunjukkan bahwa pengaruh sederhana waktu penyimpanan selama dua minggu menghasilkan persentase putih telur yang

Tabel 3. Pengaruh ransum, waktu dan suhu penyimpanan terhadap warna kuning telur (effect of ration, storage time and temperature on yolk color)

\begin{tabular}{|c|c|c|c|c|c|}
\hline \multirow{2}{*}{$\begin{array}{l}\text { Ransum } \\
\text { (rations) }\end{array}$} & \multirow{2}{*}{$\begin{array}{l}\text { Suhu penyimpanan } \\
\text { (temperature storage) }\end{array}$} & \multicolumn{3}{|c|}{$\begin{array}{l}\text { Waktu penyimpanan (minggu) } \\
\text { (storage time (week)) }\end{array}$} & \multirow{2}{*}{$\begin{array}{c}\text { Rerata } \\
\text { ransum*suhu } \\
\text { (rations }{ }^{*} \text { tempe- } \\
\text { rature average) }\end{array}$} \\
\hline & & $\begin{array}{c}1 \\
\left(1^{s t}\right)\end{array}$ & $\begin{array}{c}2 \\
\left(2^{\text {nd }}\right) \\
\end{array}$ & $\begin{array}{c}3 \\
\left(3^{\text {rd }}\right) \\
\end{array}$ & \\
\hline \multirow[b]{2}{*}{ Ro } & Referigerator (refrigerator) & $8,00 \pm 0,00^{\mathrm{ab}}$ & $6,48 \pm 1,07^{\text {cde }}$ & $4,50 \pm 0,58^{\mathrm{fg}}$ & $6,33 \pm 1,63$ \\
\hline & $\begin{array}{l}\text { Suhu ruang (room } \\
\text { temperature) }\end{array}$ & $6,75 \pm 0,96^{\mathrm{bcd}}$ & $8,75 \pm 0,50^{a}$ & $4,50 \pm 1,29^{f g}$ & $6,67 \pm 2,02$ \\
\hline \multicolumn{6}{|c|}{ Rerata ransum ${ }^{*}$ waktu (rations ${ }^{*}$ storage time } \\
\hline \multirow[b]{2}{*}{$\mathrm{R} 1$} & Referigerator (refrigerator) & $7,50 \pm 0,5^{\mathrm{abc}}$ & $7,50 \pm 0,58^{\mathrm{abc}}$ & $4,75 \pm 0,50^{f g}$ & $6,58 \pm 1,44$ \\
\hline & $\begin{array}{l}\text { Suhu ruang (room } \\
\text { temperature) }\end{array}$ & $6,75 \pm 1,50^{\mathrm{bcd}}$ & $4,50 \pm 0,58^{\mathrm{fg}}$ & $4,50 \pm 0,58^{f g}$ & $5,25 \pm 1,38$ \\
\hline \multicolumn{2}{|c|}{$\begin{array}{l}\text { Rerata ransum*waktu (rations }{ }^{*} \text { storage time } \\
\text { average) }\end{array}$} & $7,13 \pm 1,13$ & $6,00 \pm 1,31$ & $4,63 \pm 0,52$ & $5,92 \pm 1,56$ \\
\hline \multirow[b]{2}{*}{$\mathrm{R} 2$} & Referigerator (refrigerator) & $7,25 \pm 0,96^{\mathrm{bc}}$ & $7,25 \pm 0,50^{\mathrm{bc}}$ & $5,00 \pm 1,15^{\mathrm{fg}}$ & $6,50 \pm 1,16$ \\
\hline & $\begin{array}{l}\text { Suhu ruang (room } \\
\text { temperature) }\end{array}$ & $5,75 \pm 1,26^{\text {def }}$ & $6,00 \pm 1,15^{\text {cdef }}$ & $4,50 \pm 0,58^{\mathrm{fg}}$ & $5,42 \pm 1,16$ \\
\hline \multicolumn{2}{|c|}{$\begin{array}{l}\text { Rerata ransum*waktu (rations }{ }^{*} \text { storage time } \\
\text { average) }\end{array}$} & $6,50 \pm 1,31$ & $6,63 \pm 1,06$ & $4,75 \pm 0,89$ & $5,96 \pm 1,37$ \\
\hline \multirow[b]{2}{*}{ R3 } & Referigerator (refrigerator) & $5,25 \pm 0,96^{\text {efg }}$ & $7,50 \pm 0,58^{\mathrm{abc}}$ & $4,00 \pm 1,41^{9}$ & $5,58 \pm 1,78$ \\
\hline & $\begin{array}{l}\text { Suhu ruang (room } \\
\text { temperature) }\end{array}$ & $6,75 \pm 1,26^{\mathrm{bcd}}$ & $5,00 \pm 0,82^{\mathrm{fg}}$ & $8,25 \pm 0,50^{\mathrm{ab}}$ & $6,67 \pm 1,61$ \\
\hline \multicolumn{2}{|c|}{$\begin{array}{l}\text { Rerata ransum*waktu (rations }{ }^{*} \text { storage time } \\
\text { average) }\end{array}$} & $6,00 \pm 1,31$ & $6,25 \pm 1,49$ & $6,13 \pm 2,47$ & $6,13 \pm 1,75$ \\
\hline \multicolumn{2}{|c|}{$\begin{array}{l}\text { Rerata waktu penyimpanan (storage time } \\
\text { average) }\end{array}$} & $6,75 \pm 1,24$ & $6,62 \pm 1,50$ & $5,00 \pm 1,50$ & \\
\hline \multirow{2}{*}{$\begin{array}{l}\text { Rerata suhu } \\
\text { (temperatu-re } \\
\text { storage) }\end{array}$} & Referigerator (refrigerator) & $7,00 \pm 1,26$ & $7,18 \pm 0,78$ & $4,56 \pm 0,96$ & $6,25 \pm 1,57$ \\
\hline & $\begin{array}{l}\text { Suhu ruang (room } \\
\text { temperature) }\end{array}$ & $6,50 \pm 1,21$ & $6,06 \pm 1,84$ & $5,44 \pm 1,82$ & $6,00 \pm 1,68$ \\
\hline
\end{tabular}


Tabel 4. Pengaruh ransum, waktu dan suhu penyimpanan terhadap Haugh unit (effect of ration, storage time and temperature on Haugh unit)

\begin{tabular}{|c|c|c|c|c|c|}
\hline \multirow{2}{*}{$\begin{array}{l}\text { Ransum } \\
\text { (rations) }\end{array}$} & \multirow{2}{*}{$\begin{array}{l}\text { Suhu penyimpanan } \\
\text { (temperature storage) }\end{array}$} & \multicolumn{3}{|c|}{$\begin{array}{l}\text { Waktu penyimpanan (minggu) } \\
\text { (storage time (week)) }\end{array}$} & \multirow{2}{*}{$\begin{array}{c}\text { Rerata } \\
\text { ransum*suhu } \\
\text { (rations }{ }^{*} \text { tempe- } \\
\text { rature average) }\end{array}$} \\
\hline & & $\begin{array}{c}1 \\
\left(1^{s t}\right)\end{array}$ & $\begin{array}{c}2 \\
\left(2^{\text {nd }}\right) \\
\end{array}$ & $\begin{array}{c}3 \\
\left(3^{r d}\right) \\
\end{array}$ & \\
\hline \multirow{2}{*}{ Ro } & Referigerator (refrigerator) & $89,13 \pm 4,54$ & $81,97 \pm 3,25$ & $84,03 \pm 6,49$ & $85,04 \pm 5,47$ \\
\hline & $\begin{array}{l}\text { Suhu ruang (room } \\
\text { temperature) }\end{array}$ & $74,61 \pm 10,13$ & $69,08 \pm 6,13$ & $62,24 \pm 15,05$ & $68,64 \pm 11,31$ \\
\hline \multicolumn{2}{|c|}{$\begin{array}{l}\text { Rerata ransum*waktu (rations }{ }^{*} \text { storage time } \\
\text { average) }\end{array}$} & $81,87 \pm 10,63$ & $75,53 \pm 8,25$ & $73,14 \pm 15,84$ & $76,84 \pm 12,07$ \\
\hline \multirow[b]{2}{*}{ R1 } & Referigerator (refrigerator) & $87,71 \pm 3,06$ & $87,83 \pm 3,61$ & $78,94 \pm 7,91$ & $84,83 \pm 6,49$ \\
\hline & $\begin{array}{l}\text { Suhu ruang (room } \\
\text { temperature) }\end{array}$ & $74,48 \pm 16,67$ & $69,35 \pm 6,74$ & $63,68 \pm 6,21$ & $69,17 \pm 10,95$ \\
\hline \multicolumn{2}{|c|}{$\begin{array}{l}\text { Rerata ransum*waktu (rations* storage time } \\
\text { average) }\end{array}$} & $81,10 \pm 13,16$ & $78,59 \pm 11,07$ & $71,31 \pm 10,48$ & $77,00 \pm 11,89$ \\
\hline \multirow{2}{*}{$\mathrm{R} 2$} & Referigerator (refrigerator) & $87,83 \pm 4,35$ & $85,22 \pm 4,82$ & $81,01 \pm 8,24$ & $84,69 \pm 6,22$ \\
\hline & $\begin{array}{l}\text { Suhu ruang (room } \\
\text { temperature) }\end{array}$ & $81,43 \pm 4,90$ & $70,31 \pm 10,43$ & $65,08 \pm 2,65$ & $72,27 \pm 9,42$ \\
\hline \multicolumn{2}{|c|}{$\begin{array}{l}\text { Rerata ransum* }{ }^{*} \text { aktu (rations }{ }^{\star} \text { storage time } \\
\text { average) }\end{array}$} & $84,63 \pm 5,49$ & $77,76 \pm 10,96$ & $73,05 \pm 10,23$ & $78,48 \pm 10,06$ \\
\hline \multirow[b]{2}{*}{ R3 } & Referigerator (refrigerator) & $84,21 \pm 3,77$ & $86,55 \pm 3,11$ & $84,21 \pm 5,93$ & $84,99 \pm 4,17$ \\
\hline & $\begin{array}{l}\text { Suhu ruang (room } \\
\text { temperature) }\end{array}$ & $78,12 \pm 5,58$ & $71,54 \pm 4,93$ & $65,13 \pm 8,45$ & $71,60 \pm 8,08$ \\
\hline \multicolumn{2}{|c|}{$\begin{array}{l}\text { Rerata ransum*waktu (rations* }{ }^{*} \text { storage time } \\
\text { average) }\end{array}$} & $81,17 \pm 5,48$ & $79,05 \pm 8,89$ & $74,67 \pm 12,23$ & $78,29 \pm 9,29$ \\
\hline \multicolumn{2}{|c|}{$\begin{array}{l}\text { Rerata waktu penyimpanan (storage time } \\
\text { average) }\end{array}$} & $82,19 \pm 8,96^{a}$ & $77,73 \pm 9,48^{b}$ & $73,04 \pm 11,85^{c}$ & \\
\hline \multirow{2}{*}{$\begin{array}{l}\text { Rerata suhu } \\
\text { (temperature } \\
\text { storage) }\end{array}$} & Referigerator (refrigerator) & $87,22 \pm 4,02$ & $85,39 \pm 4,05$ & $82,05 \pm 6,83$ & $84,89 \pm 5,48^{a}$ \\
\hline & $\begin{array}{l}\text { Suhu ruang (room } \\
\text { temperature) }\end{array}$ & $77,16 \pm 9,79$ & $70,07 \pm 6,65$ & $64,03 \pm 8,38$ & $70,42 \pm 9,82^{b}$ \\
\hline
\end{tabular}

sangat nyata $(P<0,01)$ lebih tinggi pada suhu referigerator jika dibandingkan dengan persentase putih telur pada suhu ruang. Pengaruh sederhana penyimpanan pada suhu referigerator menghasilkan persentase putih telur sangat nyata $(P<0,01)$ lebih tinggi pada penyimpanan selama satu dan dua minggu jika dibandingkan dengan persentase putih telur pada penyimpanan selama tiga minggu. Pengaruh sederhana penyimpanan pada suhu ruang menghasilkan persentase putih telur sangat nyata $(P<0,01)$ lebih tinggi pada penyimpanan selama satu minggu jika dibandingkan dengan persentase putih telur pada penyimpanan selama dua dan tiga minggu.

Hasil penelitian menunjukkan bahwa secara numerik berat telur mengalami penurunan dari minggu ke minggu selama penyimpanan, namun secara statistik berat telur tidak nyata $(P>0,05)$ dipengaruhi oleh perlakuan ransum, waktu dan suhu penyimpanan. Suplementasi tepung kulit manggis (TKM) dan vitamin E (VE) di dalam ransum tidak menyebabkan perubahan berat telur yang disimpan pada waktu dan suhu yang berbeda. Leeson dan Summers (2005) menyatakan bahwa faktor-faktor yang mempengaruhi berat telur yaitu: genetik, umur, energi, protein dan asam amino (terutama metionina). Kandungan protein yang sama di dalam ransum diduga menyebabkan telur yang dihasilkan memiliki berat yang tidak berbeda, sehingga ketika disimpan pada suhu dan waktu yang berbeda juga tidak mengalami perubahan.

Hasil yang sama juga dilaporkan oleh Rusli et al. (2015b) bahwa suplementasi TKM dan VE di dalam ransum tidak mempengaruhi berat telur ayam ras. Scheideler et al. (2010), Irandoust et al. (2012) dan Jiang et al. (2013) menyatakan bahwa penambahan vitamin $\mathrm{E}$ di dalam ransum tidak mempengaruhi berat telur yang dihasilkan. Hasil yang berbeda dilaporkan oleh Istiqomah (2013) bahwa penambahan tepung kulit manggis $1-1,5 \%$ di 
dalam ransum meningkatkan berat telur itik Mojosari dibandingkan perlakuan kontrol, hal ini disebabkan oleh kandungan protein dan lemak yang terdapat dalam tepung kulit manggis berpengaruh terhadap peningkatan berat telur itik Mojosari pada level pemberian tertentu.

Warna kuning telur tertinggi pada penelitian ini diperoleh pada perlakuan ROM2S2 $(8,75)$ dan terendah pada perlakuan R3M3S1 (4,00). Hasil penelitian menunjukkan bahwa semakin lama waktu penyimpanan maka warna kuning telur mengalami penurunan, selain itu warna kuning telur juga dipengaruhi oleh suhu penyimpanan. Warna kuning telur lebih baik ketika disimpan pada suhu referigerator dibandingkan dengan suhu ruang, hal ini terlihat pada Tabel 3 bahwa skor warna kuning telur yang lebih besar ketika disimpan di referigerator dibandingkan disimpan pada suhu ruang.

Penurunan skor warna kuning telur selama masa penyimpanan dengan suhu yang berbeda juga dilaporkan oleh Jin et al. (2011) dan Sert et al. (2011). Maria Elena et al. (2006) menyatakan bahwa penyimpanan selama 30 hari dengan suhu $4^{\circ} \mathrm{C}$ warna kuning telur tidak berubah, akan tetapi penyimpanan pada suhu $20^{\circ} \mathrm{C}$ terjadi penurunan dari 9,91 menjadi 8,33. Penurunan warna kuning telur disebabkan terjadinya pengenceran kuning telur. Jones (2006) menyatakan bahwa selama penyimpanan, suhu di dalam telur meningkat sehingga struktur protein putih telur dan membran vitelline mengalami kerusakan dengan cepat. Kerusakan membran selama penyimpanan menyebabkan air masuk ke kuning telur sehingga terjadi pengenceran pigmen dan setelah penyimpanan yang lama kemungkinan protein putih telur masuk ke kuning telur sehingga terjadi penurunan warna kuning telur.

Hasil penelitian menunjukkan bahwa Haugh unit (HU) tidak nyata $(P>0,05)$ dipengaruhi oleh suplementasi TKM dan VE di dalam ransum. Hasil penelitian seperti ini juga dilaporkan oleh Rusli et al. (2015b) bahwa suplementasi TKM dan VE tidak mempengaruhi HU pada telur ayam (kondisi

Tabel 5. Pengaruh ransum, waktu dan suhu penyimpanan terhadap tebal kerabang $(\mathrm{mm})$ (effect of ration, storage time and temperature on shell thickness $(\mathrm{mm})$ )

\begin{tabular}{|c|c|c|c|c|c|}
\hline \multirow{2}{*}{$\begin{array}{l}\text { Ransum } \\
\text { (rations) }\end{array}$} & \multirow{2}{*}{$\begin{array}{l}\text { Suhu penyimpanan } \\
\text { (temperature storage) }\end{array}$} & \multicolumn{3}{|c|}{$\begin{array}{l}\text { Waktu penyimpanan (minggu) } \\
\text { (storage time (week)) }\end{array}$} & \multirow{2}{*}{$\begin{array}{c}\text { Rerata } \\
\text { ransum*suhu } \\
\text { (rations*tempe- } \\
\text { rature average) }\end{array}$} \\
\hline & & $\begin{array}{c}1 \\
\left(1^{s t}\right)\end{array}$ & $\begin{array}{c}2 \\
\left(2^{\text {nd }}\right)\end{array}$ & $\begin{array}{c}3 \\
\left(3^{r d}\right)\end{array}$ & \\
\hline \multirow{2}{*}{ Ro } & Referigerator (refrigerator) & $0,28 \pm 0,04$ & $0,30 \pm 0,00$ & $0,29 \pm 0,03$ & $0,29 \pm 0,03$ \\
\hline & Suhu ruang (room temperature) & $0,28 \pm 0,02$ & $0,30 \pm 0,03$ & $0,27 \pm 0,04$ & $0,28 \pm 0,03$ \\
\hline \multicolumn{2}{|c|}{$\begin{array}{l}\text { Rerata ransum }{ }^{*} \text { waktu }\left(\text { rations }^{*} \text { storage time }\right. \\
\text { average) }\end{array}$} & $0,28 \pm 0,03$ & $0,30 \pm 0,01$ & $0,28 \pm 0,03$ & $0,29 \pm 0,03^{b}$ \\
\hline \multirow{2}{*}{ R1 } & Referigerator (refrigerator) & $0,29 \pm 0,01$ & $0,29 \pm 0,01$ & $0,34 \pm 0,03$ & $0,31 \pm 0,03$ \\
\hline & Suhu ruang (room temperatc & $0,30 \pm 0,02$ & $0,31 \pm 0,02$ & $0,32 \pm 0,02$ & $0,31 \pm 0,02$ \\
\hline \multicolumn{2}{|c|}{$\begin{array}{l}\text { Rerata ransum*waktu (rations* storage time } \\
\text { average) }\end{array}$} & $0,30 \pm 0,02$ & $0,30 \pm 0,02$ & $0,33 \pm 0,03$ & $0,31 \pm 0,03^{a}$ \\
\hline \multirow{2}{*}{$\mathrm{R} 2$} & Referigerator (refrigerator) & $0,29 \pm 0,02$ & $0,31 \pm 0,02$ & $0,32 \pm 0,06$ & $0,31 \pm 0,03$ \\
\hline & Suhu ruang (room temperature) & $0,29 \pm 0,02$ & $0,28 \pm 0,03$ & $0,34 \pm 0,02$ & $0,30 \pm 0,03$ \\
\hline \multicolumn{2}{|c|}{$\begin{array}{l}\text { Rerata ransum*waktu (rations }{ }^{*} \text { storage time } \\
\text { average) }\end{array}$} & $0,29 \pm 0,02$ & $0,30 \pm 0,03$ & $0,33 \pm 0,04$ & $0,30 \pm 0,03^{a}$ \\
\hline \multirow{2}{*}{ R3 } & Referigerator (refrigerator) & $0,30 \pm 0,02$ & $0,28 \pm 0,03$ & $0,32 \pm 0,03$ & $0,30 \pm 0,03$ \\
\hline & Suhu ruang (room temperature) & $0,29 \pm 0,02$ & $0,31 \pm 0,01$ & $0,30 \pm 0,02$ & $0,30 \pm 0,02$ \\
\hline \multicolumn{2}{|c|}{$\begin{array}{l}\text { Rerata ransum*waktu (rations* storage time } \\
\text { average) }\end{array}$} & $0,29 \pm 0,02$ & $0,30 \pm 0,03$ & $0,31 \pm 0,03$ & $0,30 \pm 0,03^{b}$ \\
\hline \multicolumn{2}{|c|}{ Rerata waktu penyimpanan (storage time average) } & $0,29 \pm 0,03^{b}$ & $0,30 \pm 0,03^{b}$ & $0,31 \pm 0,03^{a}$ & \\
\hline \multirow{2}{*}{$\begin{array}{l}\text { Rerata suhu } \\
\text { (temperature } \\
\text { average) }\end{array}$} & Referigerator (refrigerator) & $0,29 \pm 0,03$ & $0,30 \pm 0,02$ & $0,32 \pm 0,04$ & $0,30 \pm 0,03$ \\
\hline & Suhu ruang (room temperature) & $0,29 \pm 0,02$ & $0,30 \pm 0,02$ & $0,31 \pm 0,04$ & $0,30 \pm 0,03$ \\
\hline \multicolumn{6}{|c|}{ 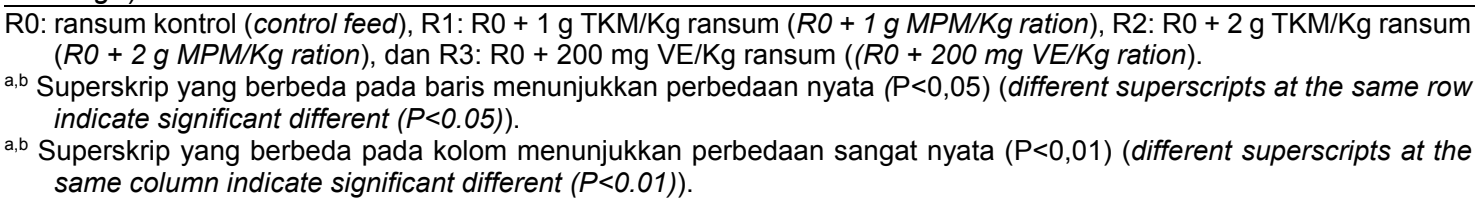 } \\
\hline
\end{tabular}


segar). Nilai $\mathrm{HU}$ yang tidak berbeda juga dilaporkan oleh Florou-Paneri et al. (2006), Irandoust et al. (2012) dan Jiang et al. (2013) yang menggunakan vitamin $E$ hingga 250 $\mathrm{mg} / \mathrm{kg}$ di dalam ransum ayam petelur.

Nilai HU selain dipengaruhi oleh berat telur dan tinggi albumen (Stadelman dan Cotterill 1995), juga dipengaruhi oleh waktu penyimpanan (Jones dan Musgrove, 2005). HU pada penelitian ini sangat nyata $(P<0,01)$ menurun dipengaruhi oleh waktu dan suhu selama penyimpanan. Semakin lama telur disimpan pada penelitian ini, maka nilai $\mathrm{HU}$ semakin menurun. Selama proses penyimpanan terjadi penguapan air dan gas $\left(\mathrm{CO}_{2}\right)$ sehingga putih telur menjadi encer (Jazil et al., 2013).

Nilai $\mathrm{HU}$ tertinggi pada penelitian ini diperoleh pada waktu minggu ke-1 $(82,19)$ dan terendah diperoleh pada waktu minggu ke-3 $(73,04)$. Jika dilihat dari segi suhu penyimpanan, nilai HU lebih tinggi pada suhu referigerator yaitu: 84,89 dibandingkan suhu ruang yaitu: 70,42 . Penurunan nilai HU juga dilaporkan oleh Jin et al. (2011) menyatakan bahwa nilai HU menurun dari 87,62 menjadi 60,92 pada suhu $29^{\circ} \mathrm{C}$ selama penyimpanan 10 hari. Berdasarkan United State Department of Agriculture (2000) nilai HU pada akhir penelitian ini tergolong ke dalam kualitas A yaitu $>60$, sedangkan Nilai HU yang bagus yaitu $>72$ (kualitas $A A$ ).

Tebal kerabang pada penelitian ini dipengaruhi oleh ransum dan waktu selama penyimpanan. Ransum perlakuan dengan suplementasi TKM dan Vitamin E memiliki telur dengan kerabang yang lebih tebal dibandingkan dengan ransum tanpa suplementasi. Tebal kerabang dari segi waktu penyimpanan pada penelitian ini menunjukkan bahwa semakin lama penyimpanan maka tebal kerabang semakin meningkat. Mekanisme atau proses yang menyebabkan peningkatan tebal kerabang dari $0,29 \mathrm{~mm}$ (minggu ke-1) menjadi $0,30 \mathrm{~mm}$ (minggu ke-3) pada penelitian ini belum dapat

Tabel 6. Pengaruh ransum, waktu dan suhu penyimpanan terhadap persentase kuning telur (effect of ration, storage time and temperature on percentage of yolk)

\begin{tabular}{|c|c|c|c|c|c|}
\hline \multirow{2}{*}{$\begin{array}{l}\text { Ransum } \\
\text { (rations) }\end{array}$} & \multirow{2}{*}{$\begin{array}{l}\text { Suhu penyimpanan } \\
\text { (temperature storage) }\end{array}$} & \multicolumn{3}{|c|}{$\begin{array}{l}\text { Waktu penyimpanan (minggu) } \\
\text { (storage time (week)) }\end{array}$} & \multirow{2}{*}{$\begin{array}{c}\text { Rerata } \\
\text { ransum*suhu } \\
\text { (rations*tempe- } \\
\text { rature average) }\end{array}$} \\
\hline & & $\begin{array}{c}1 \\
\left(1^{s t}\right)\end{array}$ & $\begin{array}{c}2 \\
\left(2^{\text {nd }}\right)\end{array}$ & $\begin{array}{c}3 \\
\left(3^{\text {rd }}\right)\end{array}$ & \\
\hline \multirow[b]{2}{*}{ Ro } & Referigerator (refrigerator) & $25,68 \pm 1,91$ & $23,15 \pm 2,44$ & $25,84 \pm 2,53$ & $24,89 \pm 2,45$ \\
\hline & $\begin{array}{l}\text { Suhu ruang (room } \\
\text { temperature) }\end{array}$ & $25,12 \pm 2,87$ & $28,21 \pm 3,02$ & $29,45 \pm 4,63$ & $27,60 \pm 3,77$ \\
\hline \multicolumn{2}{|c|}{$\begin{array}{l}\text { Rerata ransum* waktu (rations }{ }^{*} \text { storage time } \\
\text { average) }\end{array}$} & $25,40 \pm 2,27$ & $25,68 \pm 3,71$ & $27,65 \pm 3,96$ & $26,25 \pm 3,40$ \\
\hline \multirow[b]{2}{*}{ R1 } & Referigerator (refrigerator) & $23,73 \pm 1,79$ & $23,36 \pm 2,14$ & $28,55 \pm 3,70$ & $25,21 \pm 3,46$ \\
\hline & $\begin{array}{l}\text { Suhu ruang (room } \\
\text { temperature) }\end{array}$ & $24,36 \pm 1,53$ & $27,77 \pm 3,89$ & $28,43 \pm 1,36$ & $26,85 \pm 2,96$ \\
\hline \multicolumn{2}{|c|}{$\begin{array}{l}\text { Rerata ransum }{ }^{*} \text { waktu }\left(\text { rations }{ }^{*} \text { storage time }\right. \\
\text { average) }\end{array}$} & $24,04 \pm 1,58$ & $25,57 \pm 3,74$ & $28,49 \pm 2,58$ & $26,03 \pm 3,25$ \\
\hline \multirow[b]{2}{*}{$\mathrm{R} 2$} & Referigerator (refrigerator) & $24,12 \pm 0,91$ & $24,94 \pm 2,55$ & $26,03 \pm 2,07$ & $25,03 \pm 1,96$ \\
\hline & $\begin{array}{l}\text { Suhu ruang (room } \\
\text { temperature) }\end{array}$ & $25,84 \pm 4,98$ & $27,67 \pm 3,24$ & $30,00 \pm 3,80$ & $27,84 \pm 4,09$ \\
\hline \multicolumn{2}{|c|}{$\begin{array}{l}\text { Rerata ransum* waktu (rations }{ }^{*} \text { storage time } \\
\text { average) }\end{array}$} & $24,98 \pm 2,58$ & $26,30 \pm 3,07$ & $28,01 \pm 3,54$ & $26,43 \pm 3,45$ \\
\hline \multirow[b]{2}{*}{ R3 } & Referigerator (refrigerator) & $25,64 \pm 2,54$ & $24,46 \pm 2,23$ & $26,16 \pm 3,26$ & $25,42 \pm 2,56$ \\
\hline & $\begin{array}{l}\text { Suhu ruang (room } \\
\text { temperature) }\end{array}$ & $25,10 \pm 1,10$ & $26,60 \pm 2,42$ & $28,08 \pm 2,29$ & $26,59 \pm 2,23$ \\
\hline \multicolumn{2}{|c|}{$\begin{array}{l}\text { Rerata ransum* waktu (rations }{ }^{*} \text { storage time } \\
\text { average) }\end{array}$} & $25,37 \pm 1,83$ & $25,53 \pm 2,44$ & $27,12 \pm 2,80$ & $26,01 \pm 2,43$ \\
\hline \multicolumn{2}{|c|}{$\begin{array}{l}\text { Rerata waktu penyimpanan (storage time } \\
\text { average) }\end{array}$} & $24,95 \pm 2,3^{\mathrm{b}}$ & $25,77 \pm 3,14^{\mathrm{b}}$ & $27,82 \pm 3,1^{\mathrm{a}}$ & \\
\hline \multirow{2}{*}{$\begin{array}{l}\text { Rerata suhu } \\
\text { (temperature } \\
\text { average) }\end{array}$} & Referigerator (refrigerator) & $24,79 \pm 1,91$ & $23,98 \pm 2,23$ & $26,65 \pm 2,88$ & $25,14 \pm 2,58^{b}$ \\
\hline & $\begin{array}{l}\text { Suhu ruang (room } \\
\text { temperature) }\end{array}$ & $25,10 \pm 2,76$ & $27,56 \pm 2,92$ & $28,99 \pm 3,04$ & $27,22 \pm 3,27^{\mathrm{a}}$ \\
\hline
\end{tabular}


diketahui. Peningkatan tebal kerabang juga terjadi pada telur burung (Phasianus colchicus) selama penyimpanan, telur mengalami peningkatan dari 3,03 menjadi 3,66 mm (Demirel dan Kirikci, 2009). Hasil yang berbeda diperoleh Kuzniacka et al. (2005) bahwa tebal kerabang mengalami penurunan dari 3,00 menjadi $2,75 \mathrm{~mm}$, penurunan tebal kerabang tergantung umur dari burung tersebut. Tebal kerabang yang berbeda pada penelitian ini tidak mempengaruhi persentase kerabang telur, diduga perbedaan tebal kerabang yang tidak terlalu besar sehingga persentase kerabang telur relatif sama antar perlakuan. Beberapa hasil penelitian menunjukkan bahwa persentase kerabang telur tidak dipengaruhi oleh waktu penyimpanan (Ahn et al., 1999; Silversides dan Scott, 2001).

Hasil penelitian menunjukkan bahwa suplementasi TKM dan VE di dalam ransum tidak mempengaruhi $(P>0,05)$ persentase kuning telur pada waktu dan suhu penyimpanan yang berbeda. Hasil penelitian ini tidak berbeda dengan hasil penelitian Rusli et al. (2015b) menyatakan bahwa suplementasi TKM dan VE tidak mempengaruhi persentase kuning telur segar ayam petelur. Hal ini menunjukkan bahwa persentase kuning telur segar maupun disimpan pada waktu dan suhu yang berbeda tidak dipengaruhi oleh suplementasi TKM dan VE. Persentase kuning telur pada penelitian ini sangat nyata $(P<0,01)$ meningkat dipengaruhi oleh waktu dan suhu penyimpanan. Hasil penelitian menunjukkan bahwa terjadi peningkatan persentase kuning telur dari minggu ke-1 (24,95\%) sampai minggu ke-3 $(27,82 \%)$ selama penyimpanan. Dari segi suhu penyimpanan, persentase kuning telur lebih besar ketika disimpan di suhu ruang $(27,22 \%)$ daripada suhu referigerator (25,14\%). Peningkatan persentase kuning telur selama penyimpanan juga diperoleh Ahn et al. (1999), Demirel dan Kirikci (2009) dan Jin et al. (2011).

Tabel 7. Pengaruh ransum, waktu dan suhu penyimpanan terhadap persentase putih telur (effect of ration, storage time and temperature on percentage of albumen)

\begin{tabular}{|c|c|c|c|c|c|}
\hline \multirow{2}{*}{$\begin{array}{l}\text { Ransum } \\
\text { (rations) }\end{array}$} & \multirow{2}{*}{$\begin{array}{l}\text { Suhu penyimpanan } \\
\text { (temperature storage) }\end{array}$} & \multicolumn{3}{|c|}{$\begin{array}{c}\text { Waktu penyimpanan (minggu) } \\
\text { (storage time (week)) }\end{array}$} & \multirow{2}{*}{$\begin{array}{c}\text { Rerata } \\
\text { ransum*suhu } \\
\text { (rations*tempe- } \\
\text { rature average) }\end{array}$} \\
\hline & & $\begin{array}{c}1 \\
\left(1^{s t}\right)\end{array}$ & $\begin{array}{c}2 \\
\left(2^{\text {nd }}\right)\end{array}$ & $\begin{array}{c}3 \\
\left(3^{r d}\right)\end{array}$ & \\
\hline \multirow[b]{2}{*}{ R0 } & Referigerator (refrigerator) & $64,41 \pm 1,89$ & $66,41 \pm 3,43$ & $62,79 \pm 1,84$ & $64,54 \pm 2,74$ \\
\hline & $\begin{array}{l}\text { Suhu ruang (room } \\
\text { temperature) }\end{array}$ & $63,96 \pm 3,08$ & $60,69 \pm 3,51$ & $61,06 \pm 3,79$ & $61,90 \pm 3,49$ \\
\hline \multicolumn{2}{|c|}{$\begin{array}{l}\text { Rerata ransum*waktu (rations }{ }^{*} \text { storage time } \\
\text { average) }\end{array}$} & $64,18 \pm 2,38$ & $63,55 \pm 4,44$ & $61,93 \pm 2,91$ & $63,22 \pm 3,35$ \\
\hline \multirow[b]{2}{*}{$\mathrm{R} 1$} & Referigerator (refrigerator) & $65,05 \pm 2,38$ & $66,20 \pm 2,13$ & $60,59 \pm 3,03$ & $63,95 \pm 3,41$ \\
\hline & $\begin{array}{l}\text { Suhu ruang (room } \\
\text { temperature) }\end{array}$ & $64,97 \pm 0,68$ & $62,01 \pm 3,34$ & $60,41 \pm 2,17$ & $62,46 \pm 2,89$ \\
\hline \multicolumn{2}{|c|}{$\begin{array}{l}\text { Rerata ransum*waktu (rations* storage time } \\
\text { average) }\end{array}$} & $65,01 \pm 1,62$ & $64,11 \pm 3,43$ & $60,50 \pm 2,44$ & $63,20 \pm 3,18$ \\
\hline \multirow[b]{2}{*}{$\mathrm{R} 2$} & Referigerator (refrigerator) & $65,29 \pm 1,01$ & $64,32 \pm 2,86$ & $62,88 \pm 1,86$ & $64,17 \pm 2,13$ \\
\hline & $\begin{array}{l}\text { Suhu ruang (room } \\
\text { temperature) }\end{array}$ & $63,39 \pm 4,62$ & $61,32 \pm 1,73$ & $58,45 \pm 2,87$ & $61,05 \pm 3,66$ \\
\hline \multicolumn{2}{|c|}{$\begin{array}{l}\text { Rerata ransum*waktu (rations* }{ }^{*} \text { storage time } \\
\text { average) }\end{array}$} & $64,34 \pm 3,26$ & $62,82 \pm 2,71$ & $60,67 \pm 3,26$ & $62,61 \pm 3,33$ \\
\hline \multirow[b]{2}{*}{ R3 } & Referigerator (refrigerator) & $64,12 \pm 3,26$ & $66,41 \pm 2,00$ & $62,71 \pm 3,70$ & $64,41 \pm 3,20$ \\
\hline & $\begin{array}{l}\text { Suhu ruang (room } \\
\text { temperature) }\end{array}$ & $64,91 \pm 2,37$ & $62,43 \pm 3,07$ & $61,53 \pm 3,33$ & $62,96 \pm 3,06$ \\
\hline \multicolumn{2}{|c|}{$\begin{array}{l}\text { Rerata ransum }{ }^{*} \text { waktu (rations }{ }^{*} \text { storage time } \\
\text { average) }\end{array}$} & $64,51 \pm 2,67$ & $64,42 \pm 3,20$ & $62,12 \pm 3,32$ & $63,68 \pm 3,15$ \\
\hline \multicolumn{2}{|c|}{ Rerata waktu penyimpanan (storage time average) } & $64,51 \pm 2,4^{\mathrm{a}}$ & $63,72 \pm 3,3^{a}$ & $61,30 \pm 2,9^{b}$ & \\
\hline \multirow{2}{*}{$\begin{array}{l}\text { Rerata suhu } \\
\text { (temperature } \\
\text { average) }\end{array}$} & Referigerator (refrigerator) & $64,72 \pm 2,1^{\mathrm{a}}$ & $65,84 \pm 2,5^{a}$ & $62,24 \pm 2,6^{b}$ & $64,27 \pm 2,83^{a}$ \\
\hline & $\begin{array}{l}\text { Suhu ruang (room } \\
\text { temperature) }\end{array}$ & $64,30 \pm 2,8^{a}$ & $61,61 \pm 2,7^{\mathrm{b}}$ & $60,36 \pm 3,0^{b}$ & $62,09 \pm 3,26^{b}$ \\
\hline
\end{tabular}


Peningkatan persentase kuning telur selama penyimpanan diduga disebabkan oleh beberapa komponen putih telur pindah ke kuning telur, sehingga volume kuning telur bertambah (Ahn et al., 1999). Komponen putih telur terdiri atas air, protein, mineral dan vitamin (Nys dan Guyot, 2011). Komponen putih telur yang mengalami perpindahan diduga adalah air dan protein, asumsi ini terkait dari penurunan warna kuning telur pada penelitian ini yang disebabkan oleh protein dan air yang masuk ke kuning telur. Perpindahan ini juga dipengaruhi suhu penyimpanan, karena pada suhu ruang penguapan lebih besar sehingga persentase putih telur menjadi berkurang, selain menguap diduga beberapa komponen putih telur pindah ke kuning telur. Akibatnya rasio kuning telur mengalami peningkatan sedangkan persentase putih telur mengalami penurunan.

Hasil penelitian menunjukkan bahwa suplementasi TKM dan VE di dalam ransum tidak mempengaruhi $(P>0,05)$ persentase putih telur. Hasil yang sama juga dilaporkan oleh Rusli et al. (2015b) bahwa suplementasi TKM dan VE tidak mempengaruhi persentase putih telur segar ayam petelur. Penelitian ini menunjukkan bahwa faktor interaksi antara waktu dan suhu penyimpanan nyata $(P<0,05)$ menurunkan persentase putih telur. Hal ini sesuai dengan Samli et al. (2005) bahwa persentase putih telur dipengaruhi oleh faktor lingkungan seperti: suhu dan waktu penyimpanan. Persentase putih telur tertinggi diperoleh pada perlakuan M2S1 $(65,84 \%)$ dan persentase putih telur terendah pada perlakuan M3S2 (60,36\%). Penurunan persentase putih telur mengindikasikan bahwa terjadinya proses penguapan air dan gas (karbondioksida, amonia, nitrogen dan hidrogen sulfida) dari putih telur yang dapat mempengaruhi kualitas telur (Wulandari, 2004; Yosi et al., 2016).

Penelitian ini juga menunjukkan bahwa terdapat hubungan terbalik antara persentase putih telur dengan persentase kuning telur selama waktu dan suhu penyimpanan yang berbeda. Persentase putih telur terendah pada perlakuan M3S2: $60,36 \%$, sedangkan persentase kuning telur tertinggi pada perlakuan M3S2: 28,99\%. Hasil penelitian serupa juga ditemukan oleh Jin et al. (2011) bahwa berat putih telur menurun selama penyimpanan, sedangkan berat kuning telur meningkat selama penyimpanan dan suhu yang berbeda.

\section{Kesimpulan}

Suplementasi tepung kulit manggis dan Vitamin E di dalam ransum ayam ras petelur strain Lohmann secara umum tidak mempengaruhi kualitas fisik telur (kecuali warna kuning telur dan tebal kerabang) yang disimpan pada waktu dan suhu yang berbeda. Kualitas fisik telur lebih utama dipengaruhi oleh waktu dan suhu penyimpanan yang berbeda. Suhu dan kelembaban terbaik untuk penyimpanan telur adalah $4,13^{\circ} \mathrm{C}$ dan $22,50 \%$ pada refrigerator, pada kondisi ini telur dapat disimpan selama 21 hari.

\section{Ucapan Terima Kasih}

Penulis mengucapkan terima kasih kepada Direktorat Jenderal Pendidikan Tinggi Indonesia untuk mendukung penelitian ini melalui Pendanaan Penelitian ProgramBOPTN (Project ID No. 12/IT3/LT/2014).

\section{Daftar Pustaka}

Ahn, D. U., J. L. Sell, C. J, M. Chamruspollert and M. Jeffrey. 1999. Effect of dietary conjugated linoleic acid on the quality characteristics of chicken eggs during refrigerated storage. Poult. Sci. 78: 922-928.

Badan Standarisasi Nasional (BSN). 2008. SNI3926:2008. Telur Ayam Konsumsi. BSN, Jakarta.

Buckle, K. A., R. A. Edwards, G. H. Fleet and M. Wooten. 1987. Ilmu Pangan. Terjemahan oleh $\mathrm{H}$. Purnomo dan Adiono. UI Press, Jakarta.

Cornelia, A., I. K. Suada dan M. D. Rudyanto. 2014. Perbedaan daya simpan telur ayam ras yang dicelupkan dan tanpa dicelupkan larutan kulit manggis. Indonesia Medicus Veterinus 3: 112119.

Ciftci, M., O. N. Ertas and T. Guler. 2005. Effects of vitamin $E$ and vitamin C dietary supplementationon egg production and egg qualityof laying hens exposed to a chronic heat stress. Revue. Med. Vet. 156: 107-111.

Demirel, S. and K. Kırıkci. 2009. Effect of different egg storage times on some egg quality characteristics and hatchability of pheasants (Phasianus colchicus). Poult. Sci. 88: 440-444.

Florou-Paneri P. D., Dotas, I. Mitsopoulos, V. Dotas, E. Botsoglou, I. Nikolakakis and 
N. Botsoglou. 2006. Effect of feeding rosemary and $\alpha$-tocopheryl acetate on hen performance and egg quality. J. Poult. Sci. 43: 143-149.

Gutierrez-Orozco, F. and M. L. Failla. 2013. Biological activities and bioavailability of mangosteen xanthones: a critical review of the current evidence. Nutrients. 5: 3163-3183.

Irandoust, H., A. H. Samie, H. R. Rahmani, M. A. Edriss, and G. G. Mateos. 2012. Influence of source of fat and supplementation of the diet with vitamin $E$ and $C$ on performance and egg quality of laying hens from forty four to fifty six weeks of age. Anim. Feed Sci. Technol. 177: 75-85.

Istiqomah, F. 2013. Pengaruh Penggunaan Tepung Kulit Manggis (Garcinia Mangostana L) Pada Pakan Terhadap Kualitas Telur Itik Mojosari. Fakultas Peternakan, Universitas Brawijaya, Malang.

Jazil, N., A. Hintono, dan S. Mulyani. 2013. Penurunan kualitas telur ayam ras dengan intensitas warna coklat kerabang berbeda selama penyimpanan. Jurnal Aplikasi Teknologi Pangan 2: 43-47.

Jiang, W., L. Zhang and A. Shan. 2013. The effect of vitamin $E$ on laying performance and egg quality in laying hens fed corn dried distillers grains with solubles. Poult. Sci. 92: 2956-2964.

Jin, Y. H., K. T. Lee, W. I. Lee and Y. K. Han. 2011. Effects of storage temperature and time on the quality of eggs from laying hens at peak production. AsianAust. J. Anim. Sci. 24: 279-284.

Jones, D. R. 2006. Conserving and monitoring shell egg quality. Proceedings of the $18^{\text {th }}$ Annual Australian Poultry Science.

Jones, D. R. and M. T. Musgrove. 2005. Effects of Extended Storage on Egg Quality Factors. Poult. Scie. 84: 17741777.

Jung, H. A., B. N. Su, W. J. Keller, R. G. Mehta and A. D. Kinghorn. 2006. Antioxidant xanthones from the pericarp of garcinia mangostana (Mangosteen). J. Agric. Food Chem. 54: 2077-2082.

Kuzniacka, J., Z. Bernacki and M. Adamski. 2005. Effect of the date of egg-laying on the biological value of eggs and reproductive traits in pheasants (Phasianus colchicuc L.). Folia Biol. (Krakow) 53 : 73-78.
Leeson, S. and J. D. Summers. 2005. Commercial Poultry Nutrition. 3rd Ed. Ontario (CA): University Books.

Maria Elena, C. J., S. G. Leonor, M. B. Eduardo, C. D. Silvia, A. G. Avila, F. M. Benjamin, R. P. Miriam and P. G. R. Fernando. 2006. Shrimp head meal in laying hen rations and its effects on fresh and stored egg quality. INCL. 31: http://www.scielo.org.ve/scielo.php?pid $=$ S0378-18442006001. Accessed 29 October 2016.

Nys, Y. and N. Guyot. 2011. Egg formation and chemistry. In: Improving the Safety and Quality of Eggs and Eggs Products. $Y$ Nys, $M$ Bain and $F$ Immersel (Ed). Volume 1. Egg Chemistry, Production and Consumption. Woodhead Publishing Limited, Cambridge (UK).

Palapol, Y., S. Ketsa., D. Stevensonb, J. M. Cooney, A.C. Allan and I. B. Ferguson. 2009. Colour development and quality of mangosteen (Garcinia mangostana L.) fruit during ripening and after harvest. Postharvest Biol. Tech. 51: 349-353.

Puthpongsiriporn, U., S. E. Scheideler, J. L. Sell, M. M. Beck. 2001. Effects of vitamin $E$ and $C$ supplementation on performance, in vitro lymphocyte proliferation and antioxidant status of laying hens during heat stress. Poult. Sci. 80: 1190-1200.

Rahmawati, S., T. R. Setyawati, dan A. H. Yanti. 2014. Daya simpan dan kualitas telur ayam ras dilapisi minyak kelapa, kapur sirih dan ekstrak etanol kelopak rosella. Protobiont. 3: 55-60.

Rusli, R. K., K. G. Wiryawan, T. Toharmat, Jakaria and R. Mutia. 2015a. Effect of mangosteen pericarp meal and vitamin e supplements on the performance, blood profiles, antioxidant enzyme and hsp 70 gene expression of laying hens in tropical environment. Int. J. Poult. Sci. 14: 570-576.

Rusli, R. K., K. G. Wiryawan, T. Toharmat, Jakaria and R. Mutia. 2015b. Supplementation of mangosteen pericarp meal and vitamin e on egg quality and blood profile of laying hens. Med. Pet. 38: 198-203.

Samli, H. E., A. Agma and N. Senkoylu. 2005. Effects of storage time and temperature on egg quality in old laying hens. J. Appl. Poult. Res. 14: 548-553. 
Scheideler, S. E., P. Weber and D. Monsalve. 2010. Supplemental vitamin $\mathrm{E}$ and selenium effects on egg production, egg quality, and egg deposition of $\alpha-$ tocopherol and selenium. J. Appl. Poult. Res. 19 : 354-360.

Sert, D., A. Aygun and M. K. Demir. 2011. Effects of ultrasonic treatment and storage temperature on egg quality. Poult. Sci. 90: 869-875.

Silversides, F. G and T. A. Scott. 2001. Effect of storage and layer age on quality of eggs from two lines of hens. Poult. Sci. 80: 1240-1245.

Stadelman, W. J. dan O. J. Cotterill. 1995. Egg Science and Technology. $4^{\text {th }}$ edn. Food Products Press, New York.

Suvarnakuta, P., C. Chaweerungrat and S. Devahastin. 2011. Effects of drying methods on assay and antioxidant activity of xanthones in mangosteen rind. Food Chemistry. 125: 240-247.

Unites State Department of Agriculture (USDA). 2000. Egg-Grading Manual. Unites State Department of Agriculture, Washington.

Wulandari, Z. 2004. Sifat fisikokimia dan total mikroba telur itik asin hasil teknik penggaraman dan lama penyimpanan yang berbeda. Med. Pet. 27: 38-45.

Yosi, F., N. Hidayah, Julinda, dan M. L. Sari. 2016. Kualitas fisik telur asin itik pegagan yang diperoses dengan menggunakan abu pelepah kelapa sawit dan asap cair. Buletin Peternakan 40: $66-74$ 